\title{
Forage productivity and chemical composition of Panicum maximum cv. Mombaça under defoliations intensities and frequencies
}

\author{
Produtividade e composição química da forragem de Panicum maximum cv. Mombaça sob \\ intensidades e frequências de desfolhação \\ Productividad y composición química del forraje de Panicum maximum cv. Mombaça bajo \\ intensidades y frecuencias de defoliación
}

Received: 06/23/2021 | Reviewed: 07/01/2021 | Accept: 07/03/2021 | Published: 07/14/2021

Newton de Lucena Costa
ORCID: https://orcid.org/0000-0002-6853-3271
Empresa Brasileira de Pesquisa Agropecuária Roraima, Brazil
E-mail: newton.lucena-costa@embrapa.br

Liana Jank

ORCID: https://orcid.org/0000-0001-9436-3678 Empresa Brasileira de Pesquisa Agropecuária Gado de Corte, Brazil
E-mail: liana.jank@embrapa.br

João Avelar Magalhães

ORCID: https://orcid.org/0000-0002-0270-0524 Empresa Brasileira de Pesquisa Agropecuária Meio Norte, Brazil E-mail: joao.magalhaes@embrapa.br

Amaury Burlamaqui Bendahan

ORCID: https://orcid.org/0000-0002-4856-8530 Empresa Brasileira de Pesquisa Agropecuária Roraima, Brazil E-mail: amaury.bendahan@embrapa.br

Braz Henrique Nunes Rodrigues

ORCID: https://orcid.org/0000-0003-0094-63333 Empresa Brasileira de Pesquisa Agropecuária Meio Norte, Brazil E-mail: braz.rodrigues@embrapa.br

Francisco José de Seixas Santos

ORCID: https://orcid.org/0000-0002-8112-9003 Empresa Brasileira de Pesquisa Agropecuária Meio Norte, Brazil E-mail: francisco.seixas@embrapa.br

\begin{abstract}
The effects of defoliation frequency $(28,35,42$ and 49 days) and defoliation intensity (30, 40 and $50 \mathrm{~cm}$ above the ground) on green dry matter (GDM) yield, and chemical composition of Panicum maximum cv. Mombaça were evaluated under natural field conditions at the Roraima's savannas. Defoliation regimes affect productivity and chemical composition of grass forage. The decrease in the pasture defoliation frequency and intensity improved the accumulation of forage, however it reduces the tissue concentrations of $\mathrm{N}, \mathrm{P}, \mathrm{Ca}, \mathrm{Mg}$ and $\mathrm{K}$. Irrespective of defoliation frequencies, the highest levels of $\mathrm{N}\left(23.99 \mathrm{~g} \mathrm{~kg}^{-1}\right), \mathrm{P}\left(2.12 \mathrm{~g} \mathrm{~kg}^{-1}\right), \mathrm{Ca}\left(4.22 \mathrm{~g} \mathrm{~kg}^{-1}\right), \mathrm{Mg}\left(2.87 \mathrm{~g} \mathrm{~kg}^{-1}\right)$ and K $\left(21.45 \mathrm{~g} \mathrm{~kg} \mathrm{k}^{-1}\right)$ were recorded for the defoliation intensity at $40 \mathrm{~cm}$ above the ground. The use of defoliation frequency around 42 days and defoliation intensity of $42,9 \mathrm{~cm}$ above the ground can be considered adequate for the management of pastures of P. maximum cv. Mombaça, in order to provides higher forage productivity and quality, regrowth vigor, larger efficiency of forage utilization, greater tissue renewal and canopy structure more favorable to grazing.
\end{abstract}

Keywords: Calcium; Green dry matter; Magnesium; Nitrogen; Phosphorus; Potassium.

\section{Resumo}

O efeito da frequência de desfolhação $(28,35,42$ e 49 dias) e intensidade de desfolhação (30, 40 e $50 \mathrm{~cm}$ acima do solo) sobre o rendimento e composição química da forragem de Panicum maximum cv. Mombaça foi avaliado em condições de campo nos cerrados de Roraima. Os regimes de desfolhação afetaram a produtividade e a composição química da forragem da gramínea. A redução na frequência e intensidade de desfolhação resultou em maiores rendimentos de matéria seca verde, contudo, implicou em decréscimos significativos dos teores de nitrogênio $(\mathrm{N})$, fósforo $(\mathrm{P})$, cálcio $(\mathrm{Ca})$, magnésio $(\mathrm{Mg})$ e potássio $(\mathrm{K})$. Independentemente das frequências de desfolhação, as maiores concentrações de $\mathrm{N}\left(23,99 \mathrm{~g} \mathrm{~kg}^{-1}\right), \mathrm{P}\left(2,12 \mathrm{~g} \mathrm{~kg}^{-1}\right), \mathrm{Ca}\left(4,22 \mathrm{~g} \mathrm{~kg}^{-1}\right), \mathrm{Mg}\left(2,87 \mathrm{~g} \mathrm{~kg}^{-1}\right)$ e K $\left(21,45 \mathrm{~g} \mathrm{~kg}^{-1}\right)$ na forragem foram registradas com cortes a $40 \mathrm{~cm}$ acima do solo. Pastagens de P. maximum cv. Mombaça manejadas sob frequência de desfolhação em torno de 42 dias e intensidade de desfolhação de $42,9 \mathrm{~cm}$ acima do solo proporcionam 
maior produtividade e qualidade da forragem, maior eficiência de sua utilização, maior renovação de tecidos e estrutura do dossel mais favorável ao pastejo.

Palavras-chave: Cálcio; Matéria seca verde; Magnésio; Nitrogênio; Fósforo; Potássio.

\section{Resumen}

El efecto de la frecuencia de defoliación (28, 35, 42 y 49 días) y la intensidad de defoliación (30, 40 y 50 cm por encima del suelo) sobre el rendimiento de forraje y la composición química de Panicum maximum cv. Mombaça se evaluó en condiciones de campo en las sabanas de Roraima. Los regímenes de defoliación afectaron la productividad y la composición química del forraje de la gramínea. La reducción en la frecuencia e intensidad de la defoliación resultó en mayores rendimientos de materia seca verde, sin embargo, implicó disminuciones significativas en los niveles de nitrógeno $(\mathrm{N})$, fósforo $(\mathrm{P})$, calcio $(\mathrm{Ca})$, magnesio $(\mathrm{Mg})$ y potasio $(\mathrm{K})$. Independientemente de las frecuencias de defoliación, las concentraciones más altas de $\mathrm{N}\left(23,99 \mathrm{~g} \mathrm{~kg}^{-1}\right), \mathrm{P}\left(2,12 \mathrm{~g} \mathrm{~kg}^{-1}\right), \mathrm{Ca}\left(4,22 \mathrm{~g} \mathrm{~kg}^{-1}\right), \mathrm{Mg}$ $\left(2,87 \mathrm{~g} \mathrm{~kg}^{-1}\right)$ y $\mathrm{K}\left(21,45 \mathrm{~g} \mathrm{~kg}^{-1}\right)$ en el forraje se registraron con cortes a $40 \mathrm{~cm}$ por encima del suelo. Pastizales de $P$. maximum cv. Mombaça manejados bajo una frecuencia de defoliación alrededor de 42 días y una intensidad de defoliación de 42,9 cm sobre el suelo proporcionan mayor productividad y calidad del forraje, mayor eficiencia de su uso, mayor renovación de tejidos y estructura del dosel más favorable al pastoreo.

Palabras clave: Calcio; Materia seca verde; Magnesio; Nitrógeno; Fósforo; Potasio.

\section{Introduction}

In Roraima, cattle ranching is one of the most important economic activities in social, economic and environmental terms, and cultivated pastures represent the main forage resource for feeding herds (Costa et al., 2007). The species of the genus Brachiaria are the most cultivated, as they present high forage productivity in soils with low and medium natural fertility and good tolerance to the dry season. However, with the implementation of more intensive production systems, notably crop-livestock-forest integration, species of the genus Panicum are being demand, as their forage has a high nutritional value, compared to Brachiaria (Costa et al., 2007; Souza, 2018)

The use of continuous stocking combined with minimum rest periods, and high defoliation intensities are management practices that contribute to low availability and quality of forage, with negative effects on the zootechnical performance indexes of the animals (Costa et al., 2007; Alexandrino et al., 2011). Environmental conditions (temperature, light, water and soil fertility) and management practices significantly affect forage pasture productivity, while its longevity and persistense, among other factors, are consequence from the ability to reconstitute its leaf area after defoliation, which affects the structure of the canopy, determines growth speed, forage accumulation, chemical composition and persistence (Alexandrino et al., 2005; Nabinger \& Pontes, 2002; Oliveira et al. 2009).

The efficient balance between the growth of the forage plant and its consumption by the animal, aiming to ensure the stability of the soil-plant-animal system represents the central point to be reach in the management of pastures (Hodgson, 1990; Martuscello et al. 2019). Thus, a balance must be establish between productivity and quality of forage, aiming to ensure the nutritional requirements of the animals and, at the same time, maximizing the efficiency of the processes of production, use and conversion of the forage produced in animal products (meat, milk, wool, etc.).

The frequency and intensity of defoliation induce changes in the pasture morphological structure that affect the process of forage intake by the animal and modify the growth dynamics of the pasture, changing the biomass flows (Pontes et al., 2004). Defoliation intensity represents the proportion of plant tissue removed by the animal in relation to that made available for grazing, impacting the remaining photosynthetically active leaf area, the remobilization of organic reserves and the removal of apical meristems (Lemaire et al., 2011). The frequency of defoliation establishes the rest period available for the growth of the pasture and affects its productivity, chemical composition, regrowth capacity and persistence. More frequent grazing provides higher forage yields, however, concomitantly, there are marked decreases in its chemical composition, with greater accumulation of fibrous material, a decrease in the leaf/stem ratio and, consequently, less consumption by the animals (Costa et al., 2007, 2013; Lemaire et al ., 2011). 
In this work were evaluated the effects of defoliation frequency and intensity on forage accumulation and chemical composition of Panicum maximum cv. Mombaça in the Roraima's savannas.

\section{Methodology}

The research was perform under controlled conditions using the quantitative method. As there are still gaps about the effect of the intensity and frequency defoliation regimes on the productive performance of tropical forage pastures, it was choose to use the hypothetical-deductive method (Pereira et al., 2018).

The trial was conduct at the Embrapa Roraima Experimental Field, located in Boa Vista, from May to September 2016, which corresponded to an accumulated precipitation of $1,416 \mathrm{~mm}$ and an average monthly temperature of $24.79^{\circ} \mathrm{C}$. The soil of the experimental area is a Yellow Latosol, medium texture, savanna phase, with the following chemical characteristics, at a depth of 0-20 cm: $\mathrm{pH}_{\mathrm{H} 2 \mathrm{O}}=5.9 ; \mathrm{P}=16.2 \mathrm{mg} / \mathrm{kg} ; \mathrm{Ca}+\mathrm{Mg}=1.18 \mathrm{cmol}_{\mathrm{c}} \cdot \mathrm{dm}^{-3} ; \mathrm{K}=0.024 \mathrm{cmol}_{\mathrm{c}} \mathrm{dm}^{-3} \mathrm{and} \mathrm{Al}=0.11 \mathrm{cmol}_{\mathrm{c}} \mathrm{dm}^{-}$ 3 .

The experimental design was entirely randomize with three replications. The treatments consisted of four defoliation frequencies (28, 35, 42 and 49 days) and three defoliation intensities (30, 40 and $50 \mathrm{~cm}$ above the ground). The establishment fertilization consisted of the application of $80 \mathrm{~kg}$ of N ha-1, $50 \mathrm{~kg}$ of $\mathrm{P}_{2} \mathrm{O} 5 \mathrm{ha}^{-1}$ and $60 \mathrm{~kg}$ of $\mathrm{K}_{2} \mathrm{O}$ ha ${ }^{-1}$, in the form of urea, triple superphosphate and potassium chloride, respectively. The nitrogen fertilization was parcel in two times, being $1 / 3$ when planting, and $2 / 3$ at 21 days. The plots measured $2.0 \times 2.0 \mathrm{~m}$, with a useful area of $1.0 \mathrm{~m}^{2}$. During the experimental period were made 6, 5, 4 and 3 cuts, respectively for defoliation frequencies of 28, 35, 42 and 49 days.

The evaluated parameters were green dry matter (GDM) yield, nitrogen (N), phosphorus (P), calcium (Ca), magnesium $(\mathrm{Mg})$ and potassium $(\mathrm{K})$ concentrations. The $\mathrm{N}$ levels were analyzed according to the procedures described by Silva \& Queiroz (2002); while the levels of P, Ca, Mg and K were determined according to the methodology described by Silva (2009). The levels of P and K were quantify after nitroperchloric digestion. P was determined by colorimetry; K by flame photometry and $\mathrm{Ca}$ and $\mathrm{Mg}$ concentrations by atomic absorption spectrophotometry.

The data were subject to analysis of variance and regression considering the significance level of 5\% probability. In order to estimate the response of the parameters evaluated to the defoliation frequency and intensity, the choice of regression models was reasoned on the significance of the linear and quadratic coefficients, using the Student's " $t$ "test, at the level of 5\% probability.

\section{Results and Discussion}

Defoliation frequencies and intensities significantly affected $(\mathrm{P}<0.05)$ GDM yields. The effect of the defoliation intensity was adjusted to the quadratic regression model $\left(\mathrm{Y}=3,581+359.26 \mathrm{X}-4.1827 \mathrm{X}^{2}\left[\mathrm{R}^{2}=0.91\right]\right)$ and the maximum value was estimated at $42.9 \mathrm{~cm}$ above the ground (Table 1). By increasing the intensity of defoliation, the greater the amount of forage removed. However, it is necessary to provide more time for grasses to restore their growth rates. For an adequate management of pastures, defoliation intensity and frequency must be reconciled, in order to ensure forage productivity and quality, and mainly its persistence. Costa et al. (2020a) estimated that $28.2 \mathrm{~cm}$ above the ground was the best defoliation intensity for M. maximus cv. Tamani pastures, which was highly correlated to the higher tiller population density and higher rates of leaf appearance and expansion and lower leaf senescence. Tesk et al. (2020) recommend for pastures of M. maximus cvs. Tamani and Kenya the use of grazing intensities of 25 and $35 \mathrm{~cm}$ above the ground, respectively, which were correlated to high forage yields and higher recovery speed after the grazing. Oliveira et al. (2014) evaluating P. maximum cv. Mombaça pastures submitted to defoliation frequencies of 30,60 and 90 days, reported that forage yields were directly proportional to the 
rest period (3,9; 4,4 and 22,8 $\mathrm{tha}^{-1}$ of GDM, respectively), however the opposite was found for the percentage of grass leaves (96.1; 81.9 and $50.9 \%$, respectively).

Table 1. Green dry matter $\left(\mathrm{kg} \mathrm{ha}^{-1}\right)$ yield of Panicum maximum $\mathrm{cv}$. Mombaça, as affected by defoliation frequency and intensity.

\begin{tabular}{cccccc}
\hline Defoliation & \multicolumn{3}{c}{ Defoliation Frequency (days) } & \multirow{2}{*}{ Regression Equation } \\
\cline { 2 - 4 } Intensity $(\mathrm{cm})$ & 28 & 35 & 42 & 49 & \\
\hline 30 & 2,567 & 3,347 & 3,943 & 3,657 & \\
40 & 3,126 & 4,298 & 4,511 & 4,077 & $\mathrm{Y}=9,476+474.01 \mathrm{X}-5.4388 \mathrm{X}^{2}\left(\mathrm{R}^{2}=0,93\right)$ \\
50 & 2,877 & 3,956 & 4,297 & 3,989 & $\mathrm{Y}=8,298+597.43 \mathrm{X}-8.1939 \mathrm{X}^{2}\left(\mathrm{R}^{2}=0,86\right)$ \\
\hline
\end{tabular}

Source: Research Data.

Defoliation induces drastic changes in the pasture canopy with direct and significant effects on the grazing process, which can negatively compromise animal performance. Palhano et al. (2007) evaluated the influence of tropical grass $P$. maximum cv. Mombaça sward structure $(60,80,100,120$, and $140 \mathrm{~cm})$ on the intake of grazing cattle. The ingestive behavior of grazing animals was sensitive to variations in forage canopy structure. In conditions of high forage supply, efficiency of the grazing process may be limit by the difficulty of apprehension of leaf blades. Since the increase in time per bit was proportionally greater than the increase in the bite mass, the total forage mass consumed and the ingestion rate stabilized at the highest heights of the pasture (Barbosa et al., 2007; Cruz et al., 2021). The physical limitations imposed by the canopy structure led to lower efficiency forage capture by the animals at the highest heights of the canopy. Forage consumption was maximize at a height of $109.3 \mathrm{~cm}$ and animals adjust their patterns of displacement and forage search in response to forage canopy structure. (Barbosa et al., 2005; Palhano et al., 2005; 2006).

The reduction in defoliation intensity allows the retention of greater leaf area photosynthetically active and greater remobilization of nutrients, resulting in greater speed of recovery and shorter interval between grazing (Nabinger \& Carvalho, 2009, Pereira, 2013; Silva, 2019). Costa et al. (2008) estimated higher GDM yields for P. maximum cv. Vencedor managed under defoliation intensities of $40 \mathrm{~cm}$ above ground $\left(4,341 \mathrm{~kg} \mathrm{ha}^{-1}\right)$, compared to $30 \mathrm{~cm}\left(3,089 \mathrm{~kg} \mathrm{ha}^{-1}\right)$ or $20 \mathrm{~cm}\left(2,511 \mathrm{~kg} \mathrm{ha}^{-}\right.$ $\left.{ }^{1}\right)$. For pastures of P. maximum cv. Tanzania-1, Canto et al. (2008) reported linear forage availability increases with the reduction in defoliation intensity $\left(2,810 ; 3,155 ; 3,678\right.$ and 4,110 $\mathrm{kg}_{\text {of }} \mathrm{DM} \mathrm{ha}{ }^{-1}$,respectively to $20,40,60$ and $80 \mathrm{~cm}$ above the ground). Silveira (2020) reported higher forage yield of P. maximum cv. Mombaça under defoliation intensity of $50 \mathrm{~cm}$ above ground $\left(8,600 \mathrm{~kg} \mathrm{ha}^{-1}\right.$ of DM), compared to $25 \mathrm{~cm}\left(7,135 \mathrm{~kg} \mathrm{ha}^{-1}\right.$ of DM), as a consequence of their higher daily rate of forage accumulation $\left(164,9 \times 90,6 \mathrm{~kg}_{\text {of }} \mathrm{DM} \mathrm{ha}^{-1} \mathrm{day}^{-1}\right)$. Similar behavior was obtain by José et al. (2017) for P. maximum cv. Aruana pastures $\left(5,505 ; 4,795\right.$ and 4,715 $\mathrm{kg}_{\text {of }} \mathrm{DM} \mathrm{ha}^{-1}$, respectively for defoliation intensities of 40; 50 and 60\%). Costa et al. (2020b) found that the best defoliation frequency for pastures of P. maximum cv. Tamani was estimate at 38.4 days, which showed a high correlation with tiller density and leaf area index and lower leaf senescence.

The effect of the defoliation frequency on GDM yields was adjust to the quadratic regression model and the maximum values were estimated at 43.6; 41.0 and 42.5 days, respectively to defoliation intensities of 30, 40 and $50 \mathrm{~cm}$ above the ground (Table 1). Forage grasses subjected to greater defoliation intensities need longer rest periods in order to restore their organic reserves, especially non-structural carbohydrates, and the formation of new leaves, which favors the appearance of a new generation of tillers. In the Rondônia's savannas, for pastures of P. maximum cvs. Massai and Tanzânia-1, Costa et al. (2007) reported higher forage yields for defoliation frequencies varying between 28 and 35 days, which were directly correlate with the rate of appearance and leaf expansion. For higher defoliation frequencies, the regrowth speed show a high correlation with the preservation of apical meristems, whose preservation stimulates the formation of photosynthetic tissues through the 
expansion of new leaves, while the removal of apical meristems imply slower growth and originates the from the development of buds, notably of basal origin, for the production of new leaves (Pena et al., 2009; Difante et al., 2011; Cunha et al., 2012).

For P. maximum cv. Tanzânia-1 pastures, Santos et al. (2003) and Santos et al. (2012) recommend that adequate interval between grazing was obtained with 38-day rest periods from October to April; 28 days in the grass reproductive phase (April and May) and about 48 days between May and September. In pastures of P. maximum cv. Aruana, the prolongation of the defoliation frequency negatively affected the structure of its canopy, reducing the leaf/stem ratio and the tillers population, however, morphological and structural adaptations of the forage canopy allowed satisfactory regrowth under management in which the frequency between defoliation allows 4.0 new tiller ${ }^{-1}$ leaves to appear during the rainy season. The adequate defoliation frequency in grass-Tanzania-1 pastures should not exceed 35 days and coincide with the appearance of at least 3.5 fully expanded leaves per tiller (Pena et al., 2009; Ferlin et al., 2006; Gomide et al., 2007).

The concentrations of $\mathrm{N}, \mathrm{P}, \mathrm{Ca}, \mathrm{Mg}$ and $\mathrm{K}$ were negatively and linearly affect by defoliation frequencies, which demonstrates a dilution effect of their contents with a reduction in defoliation frequency due to greater forage accumulation (Table 2). Pastures of P. maximum cv. Mombaça provided significant reductions in $\mathrm{N}$ contents, by increasing the rest period, as a consequence of the increase in neutral detergent fiber and acid detergent fiber contents, reduction in the leaf/stem ratio, with negative effects on forage intake by the animals (Cândido et al., 2005a,b,c). For all defoliation frequencies, the highest concentrations of $\mathrm{N}\left(23.99 \mathrm{~g} \mathrm{~kg}^{-1}\right), \mathrm{P}\left(2.12 \mathrm{~g} \mathrm{~kg}^{-1}\right), \mathrm{Ca}\left(4.22 \mathrm{~g} \mathrm{~kg}^{-1}\right), \mathrm{Mg}\left(2.87 \mathrm{~g} \mathrm{~kg}^{-1}\right)$ and $\mathrm{K}\left(21.45 \mathrm{~g} \mathrm{~kg}^{-1}\right)$ were record for the defoliation intensity at $40 \mathrm{~cm}$ above the ground. In pastures of $P$. maximum cv. Tanzania-1, Resende Júnior (2011) found no effect of defoliation intensity (20,30 and $50 \mathrm{~cm}$ above the ground) on the contents of $\mathrm{N}, \mathrm{P}, \mathrm{Ca}$ and $\mathrm{K}$, however, for $\mathrm{Mg}$ the highest content was observe with defoliations $30 \mathrm{~cm}$ above the ground. Possibly, this behavior was a consequence of the adopted defoliation frequency, which was established when the grass intercepted $95 \%$ of the incident photosynthetically active radiation (PAR). Likewise, Carpejani (2014) using the PAR interception concept, as a criterion for the beginning grazing pasture of P. maximum cv. Mombaça submit to defoliation intensities of 30 and $50 \mathrm{~cm}$ above the ground, reported nonsignificant differences for $\mathrm{N}$ contents and the organic matter in vitro digestibility coefficient, however higher levels of neutral detergent fiber were estimate with defoliation at $30 \mathrm{~cm}$ above the ground. 
Table 2. Nitrogen, phosphorus, calcium, magnesium and potassium concentrations of Panicum maximum cv. Mombaça, as affected by defoliation frequency and intensity.

\begin{tabular}{|c|c|c|c|c|c|}
\hline \multirow{2}{*}{$\begin{array}{c}\text { Defoliation } \\
\text { Intensity }(\mathrm{cm})\end{array}$} & \multicolumn{4}{|c|}{ Defoliation Frequency (days) } & \multirow{2}{*}{ Regression Equation } \\
\hline & 28 & 35 & 42 & 49 & \\
\hline \multicolumn{6}{|c|}{ Nitrogen $\left(\mathrm{g} \mathrm{kg}^{-1}\right)$} \\
\hline 30 & 24.31 & 23.11 & 20.18 & 19.04 & $Y=31.97-0.2677 \times\left(r^{2}=0,90\right)$ \\
\hline 40 & 25.01 & 23.98 & 22.21 & 20.55 & $\mathrm{Y}=31.91-0.2164 \times\left(\mathrm{r}^{2}=0.93\right)$ \\
\hline 50 & 26.18 & 24.89 & 23.24 & 21.67 & $Y=32.34-0.2169 \times\left(r^{2}=0,95\right)$ \\
\hline \multicolumn{6}{|c|}{ Phosphorus ( $\left.\mathrm{g} \mathrm{kg}^{-1}\right)$} \\
\hline 30 & 1.89 & 1.85 & 1.63 & 1.59 & $\mathrm{Y}=2.35-0.0164 \times\left(\mathrm{r}^{2}=0,91\right)$ \\
\hline 40 & 2.18 & 2.01 & 1.86 & 1.77 & $Y=2.71-0.0197 \times\left(r^{2}=0.86\right)$ \\
\hline 50 & 2.37 & 2.21 & 1.97 & 1,91 & $Y=3.01-0.0231 \times\left(r^{2}=0.92\right)$ \\
\hline \multicolumn{6}{|c|}{ Calcium $\left(\mathrm{g} \mathrm{kg}^{-1}\right)$} \\
\hline 30 & 4.58 & 4.21 & 3.91 & 3.75 & $Y=5.64-0.0399 \times\left(r^{2}=0,87\right)$ \\
\hline 40 & 4.54 & 4.02 & 3.93 & 3.83 & $Y=5.23-0.1237 \times\left(r^{2}=0.96\right)$ \\
\hline 50 & 4.61 & 4.32 & 4.09 & 3.89 & $\mathrm{Y}=5.54-0.0341 \times\left(\mathrm{r}^{2}=0.88\right)$ \\
\hline \multicolumn{6}{|c|}{ Magnesium ( $\left.\mathrm{g} \mathrm{kg}^{-1}\right)$} \\
\hline 30 & 2.61 & 2.43 & 2.11 & 1.97 & $Y=3.51-0.0324 \times\left(r^{2}=0,92\right)$ \\
\hline 40 & 2.81 & 2.39 & 2.08 & 1.99 & $Y=3.84-0.0397 \times\left(r^{2}=0.94\right)$ \\
\hline 50 & 3.08 & 2.96 & 2.76 & 2.71 & $Y=3.59-0.0187 \times\left(r^{2}=0.96\right)$ \\
\hline \multicolumn{6}{|c|}{ Potassium $\left(\mathrm{g} \mathrm{kg}^{-1}\right)$} \\
\hline 20 & 21.03 & 18.77 & 18.05 & 17.47 & $Y=25.11-0.1629 \times\left(r^{2}=0,95\right)$ \\
\hline 30 & 21.34 & 20.67 & 19.36 & 18.89 & $\mathrm{Y}=24.82-0.1233 \times\left(\mathrm{r}^{2}=0.91\right)$ \\
\hline 40 & 23.05 & 21.87 & 20.57 & 20.33 & $Y=26.65-0.1351 \times\left(r^{2}=0.90\right)$ \\
\hline
\end{tabular}

Source: Research Data.

The mineral contents estimated in this work were similar to or higher than those reported by Costa et al. (2007) for pastures of P. maximum cvs. Tanzânia-1, Massai and Vencedor, submitted to different defoliation frequencies (21, 35, 42 and 49 days). For $\mathrm{P}, \mathrm{Ca}, \mathrm{Mg}$ and $\mathrm{K}$, the concentrations estimated with defoliation frequency of up to 28 days were higher than the

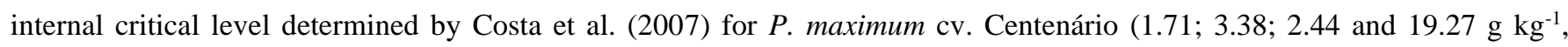
respectively for $\mathrm{P}, \mathrm{Ca}, \mathrm{Mg}$ and $\mathrm{K})$. However, Costa et al. (2020c), evaluated pastures of P. maximum cv. Tanzânia-1 and reported maximum concentrations of $\mathrm{N}, \mathrm{P}, \mathrm{K}, \mathrm{Ca}$ and $\mathrm{Mg}$, respectively at 28, 42, 35, 49 and 21 days of defoliation frequency.

The reduction in the frequency of defoliation implies a marked decrease in the nutritive value of the forage, as it maximizes the occurrence of the leaf senescence process, due to the self-shading of the basal leaves by the leaves positioned in the upper portion of the plant. Likewise, the increase in defoliation intensity induces forage intake by animals with a high proportion of senescent leaves, which have low nutrient content that limit the adequate performance of the animals. Leaf senescence expresses the process of competition for metabolites and nutrients between old and young leaves in growth, which reduces the availability of good quality forage (Santos et al., 2004; Lemaire et al., 2011; Almeida, 2015). However, the represents the natural physiological process that characterizes the last phase of leaf development, starting after its complete expansion and progressively accentuated with the increase in the leaf area, due to the shading of the leaves inserted in the portion bottom. Furthermore, the low supply of PAR intensifies the competition for light, nutrients and water between the different strata of the forage grass (Nabinger \& Pontes, 2002). However, leaf senescence represents an important physiological process in the dynamics of the grass tissue flow, since about 35;68; 86 and $42 \%$ of $\mathrm{N}, \mathrm{P}, \mathrm{K}$ and $\mathrm{Mg}$, respectively, can be recycled from senescent leaves and used for the production of new leaf tissues (Sarmiento et al., 2006; Costa et al., 2013). 


\section{Final Considerations}

Defoliation regimes affect productivity and chemical composition of Panicum maximum cv. Mombaça forage. The decrease in the pasture defoliation frequency and intensity improved the forage accumulation, however it reduces the tissue concentrations of $\mathrm{N}, \mathrm{P}, \mathrm{Ca}, \mathrm{Mg}$ and $\mathrm{K}$.

The use of defoliation frequency around 42 days and defoliation intensity of $42,9 \mathrm{~cm}$ above the ground can be considered adequate for the management of pastures of $P$. maximum cv. Mombaça, in order to reconcile production, regrowth vigor and forage quality.

The installation of experiments under field conditions are suggest and preferably with the use of animals in order to endorse the recommended defoliation regimes management for the grass.

\section{References}

Almeida, O. G. (2015). Morfogênese e produção de acessos de Panicum maximum. 43 f. Monografia. (Bacharelado em Zootecnia). Universidade Federal de São João del Rei.

Alexandrino, E., Cândido, M. J. D. \& Gomide, J. A. (2011). Fluxo de biomassa e taxa de acúmulo de forragem em capim Mombaça mantido sob diferentes alturas. Revista Brasileira de Saúde e Produção Animal, 12(1), 59-71. https://doi.org/www.rbspa.ufba.br

Alexandrino, E., Gomide, C. A. M., Cândido, M. J. D. \& Gomide, J. A. (2005). Período de descanso, características estruturais do dossel e ganho de peso vivo de novilhos em pastagem de capim-mombaça sob lotação intermitente. Revista Brasileira de Zootecnia, 34, $2174-2184$. https://doi.org/10.1590/S1516-35982005000700003

Barbosa, R. A., Nascimento Júnior, D., Euclides, V. P. B., Regazzi, A. J. \& Fonseca, D. M. (2002). Características morfogênicas e acúmulo de forragem do capim-tanzânia. Revista Brasileira de Zootecnia, 31, 583-593. http://dx.doi.org/10.1590/S1516-35982002000300007

Barbosa, R. A., Nascimento Júnior, D., Euclides, V. P. B., Silva, S.C., Zimmer, A. H. \& Torres Júnior, R. A. A. (2007). Capim-tanzânia submetido a combinações entre intensidade e frequência de pastejo. Pesquisa Agropecuária Brasileira, 42, 329-340. http://dx.doi.org/10.1590/S0100204X2007000300005

Cândido, M. J. D., Alexandrino, E. \& Gomide, J. A. (2005a). Duração do período de descanso e crescimento do dossel de Panicum maximum cv. Mombaça sob lotação intermitente. Revista Brasileira de Zootecnia, 34 (2), 398-405. https://doi.org/10.1590/S1516- 35982005000200006

Cândido, M. J. D., Gomide, C. A. M., Alexandrino, E., Gomide, J. A., \& Pereira, W. E. (2005b). Morfofisilogia do dossel de Panicum maximum cv. Mombaça sob lotação intermitente. Revista Brasileira de Zootecnia, 34 (2), 406-415. https://doi.org/10.1590/S1516-35982005000200007

Cândido, M. J. D., Alexandrino, E., Gomide, J. A., Gomide, C. A. \& Pereira, W. E. (2005c). Período de descanso, valor nutritivo e desempenho animal em pastagem de Panicum maximum cv Mombaça sob lotação intermitente. Revista Brasileira de Zootecnia, 34 (5), 1449-1458. https://doi.org/10.1590/S151635982005000500005

Canto, M. E., Jobim, C. C., Gasparino, E. \& Hoeschl, A. R. (2008). Características do pasto e acúmulo de forragem em capim-tanzânia submetido a alturas de manejo do pasto. Pesquisa Agropecuária Brasileira, 43, 429-435. http://doi.org/10.1590/S0100-204X2008000300019

Carpejani, G. C. (2014). Estratégias de manejo rotacionado em pastos de capim-mombaça. 64 f. Tese. (Doutorado em Ciência Animal). Universidade Federal do Mato Grosso do Sul.

Costa, N. L., Jank, L., Magalhães, J. A., Rodrigues, A. N. A., Bendahan, A. B., Gianluppi, V., Rodrigues, B. H. N. \& Santos, F. J. S. (2020a). Forage accumulation and morphogenetic and structural characteristics of Megathyrsus maximus cv. Tamani under defoliation intensities. PubVet, $14,4$. http://dx.doi.org/10.31533/pubvet.v14n4a553.1-7

Costa, N. L., Jank, L., Magalhães, J. A., Rodrigues, A. N. A., Bendahan, A. B., Gianluppi, V., Rodrigues, B. H. N. \& Santos, F. J. S. (2020b). Productive performance, chemical composition and morphogenesis of Megathyrsus maximus cv. Tamani under rest periods. PubVet, $14,4$. http://dx.doi.org/10.31533/pubvet.v14n4a554.1-8

Costa, N. L., Jank, L., Bendahan, A. B., Magalhães, J. A., Santos, F. J. S. \& Rodrigues, B. H. N. (2020c). Composição química e morfogênese de Panicum maximum cv. Tanzânia-1 sob frequências de desfolhação. Boa Vista: Embrapa Roraima. 16p. (Boletim de Pesquisa e Desenvolvimento, 49).

Costa, N. L., Magalhães, J. A., Pereira, R. G. A., Townsend, C. R. \& Oliveira, J. R. C. (2007). Considerações sobre o manejo de pastagens na Amazônia Ocidental. Revista do Conselho Federal de Medicina Veterinária, 40, 37-56.

Costa, N. L., Moraes, A., Monteiro, A. L. G., Motta, A. C. V., Oliveira, R. A. \& Rodrigues, A. N. A. (2013). Forage productivity and morphogenesis of Axonopus aureus under different nitrogen fertilization rates. Revista Brasileira de Zootecnia, 42, 541-548. https://doi.org/10.1590/S151635982013000800002

Cruz, N. T., Pires, A. J. V., Fries, D. D., Jardim R. R. \& Sousa B. M. L. (2021). Fatores que afetam as características morfogênicas e estruturais de plantas forrageiras. Research, Society and Development, 10 (7), e5410716180. https://dx.doi.org/10.33448/rsd-v10i7.16180 
Cunha, F. F., Mota Ramos, M., Brasileiro, A. C. A., Alves, O., Rubens, Cóser, A. C., Martins, C. E., Cecon, P. R. \& Silva, A. R. A. (2012). Produtividade da Brachiaria brizantha cv. Xaraés em diferentes manejos e doses de adubação, períodos de descanso e épocas do ano. Idesia (Arica), 30 (1), 75-82. http://dx.doi.org/10.4067/S0718-34292012000100009

Difante, G. S., Nascimento Júnior, D., Silva, S. C., Euclides, V. P. B. \& Montagner, D. B. (2011). Características morfogênicas e estruturais do capimmarandu submetido a combinações de alturas e intervalos de corte. Revista Brasileira de Zootecnia, 40 (5), 955-963. http://dx.doi.org/10.1590/S0151635982011000500003

Ferlin, M. B., Euclides, V. P. B., Lempp, B., Gonçalves, M. C. \& Cubas, C. C. (2006). Morfogênese e dinâmica de perfilhamento de Panicum maximum Jacq. cv. Tanzânia-1 sob pastejo. Ciência e Agrotecnologia, 30, 344-352. https://doi.org/10.1590/S1413-70542006000200022

Gomide, C. A. M., Gomide, J. A. \& Alexandrino, E. (2007). Características estruturais e produção de forragem em pastos de capim-mombaça submetidos a períodos de descanso. Pesquisa Agropecuária Brasileira, 42, 1487-1494. http://dx.doi.org/10.1590/S0100-204X2007001000017

Hodgson, J. (1990). Grazing management. Science into practice. Longman Group UK Ltd. 203p.

José, R. M., Mocelin, N. G. \& Zanini, G. D. (2017). Avaliações agronômicas em pastos de capim Aruana submetidos a três proporções de desfolha. VIII Seminário de Ensino, Pesquisa e Extensão do UNIBAVE-SENPEX. Epagri. 1-12.

Lemaire, G., Hodgson, J. \& Chabbi, A. (2011). Grassland productivity and ecosystem services. Cabi, Wallingford. 287p.

Martuscello, J. A., Rios, J. F., Ferreira, M. R., Assis, J. A., Braz, T. G. S. \& Cunha, D. N. F. (2019). Produção e morfogênese de capim BRS Tamani sob diferentes doses de nitrogênio e intensidades de desfolhação. Boletim de Indústria Animal, 76, 1-10. https://doi.org/10.17523/bia.2019.v76.e1441

Nabinger, C. \& Carvalho, P. C. F. (2009). Ecofisiología de sistemas pastoriles: aplicaciones para su sustentabilidad. Agrociencia, $13,18-27$.

Nabinger, C. \& Pontes, L. S. (2002). Manejo da desfolha. Simpósio sobre manejo da pastagem. FEALQ, p.133-158.

Nascimento, H. L. B. (2014). Cultivares de Panicum maximum adubadas e manejadas com frequência de desfolhação correspondente a 95\% de interceptação luminosa. 67 f. Dissertação. (Mestrado em Zootecnia). Universidade Federal de Viçosa.

Oliveira, P. S. R., Castagnara, D. D., Júnior Gonçalves, A. C., Mesquita, E. E. \& Neres, M. A. (2009). Teores de macrominerais em Panicum maximum cvs. Massai e Mombaça. Synergismus Scyentifica, 4, 7-10.

Oliveira, Z. F., Santana Júnior, H. A. \& Santana, E. O. C. (2014). Produção e composição de gramíneas da espécie Panuicum maximum. Revista Eletrônica Nutritime, 285 (11), 3820-3827.

Palhano, A. L., Carvalho, P. C. F., Ditteich, J. R., Moraes, A., Silva, S. C. \& Monteiro, A. L. G. (2007). Características do processo de ingestão de forragem por novilhas holandesas em pastagens de capim-mombaça. Revista Brasileira de Zootecnia, 36 (4), 1014-1021. https://doi.org/10.1590/S151635982007000500005

Palhano, A. L., Carvalho, P. C. F., Dittrich, J. R., Moraes, A., Barreto, M. Z. \& Santos, M. C. F. (2005). Estrutura da pastagem e padrões de desfolhação em capim-mombaça em diferentes alturas do dossel forrageiro. Revista Brasileira de Zootecnia, 34 (6), 1860-1870. https://doi.org/10.1590/S151635982005000600009

Palhano, A. L., Carvalho, P. C. F., Dittrich, J. R., Moraes, A., Silva, S. C., \& Monteiro, A. L. G. (2006). Padrões de deslocamento e procura por forragem de novilhas leiteiras em pastagem de capim-mombaça. Revista Brasileira de Zootecnia, 35 (6), 2253-2259. https://doi.org/10.1590/S151635982006000800008

Pena, K. S., Nascimento Júnior, D., Silva, S. C., Euclides, V. P. B. \& Zanine, A. M. (2009). Características morfogênicas, estruturais e acúmulo de forragem do capim-tanzânia submetido a duas alturas e três intervalos de corte. Revista Brasileira de Zootecnia, 38, 2127-2136. http://dx.doi.org/10.1590/S1516-35982009001100009

Pereira, A. S., Shitsuka, D. M., Pereira, F. J., \& Shitsuka, R. (2018). Metodologia da pesquisa científica. UFSM. https://repositorio.ufsm.br/bitstream/handle/1/15824/Lic_Computacao Metodologia PesquisaCientifica.pdf?sequence=1 .

Pereira, V. V. (2013). A importância das características morfogênicas sobre o fluxo de tecidos no manejo de pastagens tropicais. Revista em Agronegócios e Meio Ambiente, 6, 289-309.

Resende Júnior, A. J. (2011). Morfogênese, acúmulo de forragem e teores de nutrientes de Panicum maximum cv. Tanzânia submetido a diferentes severidades de desfolhação e fertilizações contrastantes. 103 f. Dissertação. (Mestrado em Ciência Animal e Pastagens). Escola Superior de Agricultura Luiz de Queiroz.

Santos, P. M., Balsalobre, M. A. A. \& Corsi, M. (2004). Características morfogenéticas e taxa de acúmulo de forragem do capim-mombaça submetido a três intervalos de pastejo. Revista Brasileira de Zootecnia, 33 (3), 843-851. http://dx.doi.org/10.1590/S01516-35982004000400004

Santos, P. M., Balsalobre, M.A.A. \& Corsi, M. (2003). Morphogenetic characteristics and management of Tanzania grass. Pesquisa Agropecuária Brasileira, 38 (8), 991-997. http://dx.doi.org/10.1590/S0100-204X2003000800012

Santos, M. R., Fonseca, D. M., Gomes, V. M., Silva, S. P., Silva, G. P. \& Reis, M. (2012). Correlações entre características morfogênicas e estruturais em pastos de capim-braquiária. Ciência Animal Brasileira, 13 (1), 49-56. http://dx.doi.org/10.5216/cab.v13i1.13401

Sarmiento, G., Silva, M. P., Naranjo, M. E. \& Pinillos, M. (2006). Nitrogen and phosphorus as limiting factors for growth and primary production in a flooded savanna in the Venezuelan Llanos. Journal of Tropical Ecology, 22 (3), 203-212. https://doi.org/10.1017/S0266467405003068 
Research, Society and Development, v. 10, n. 8, e42910817494, 2021

(CC BY 4.0) | ISSN 2525-3409 | DOI: http://dx.doi.org/10.33448/rsd-v10i8.17494

Silva, G. S. (2019). Capim Tamani na região amazônica sob adubação nitrogenada e alturas de resíduo. 39 f. Monografia. (Bacharelado em Engenharia Agronômica). Universidade Federal Rural da Amazônia. https://doi.org/10.1017/S0021-859612000858

Silva, D. J. \& Queiroz, A. C. (2002). Análise de alimentos: métodos químicos e biológicos, (3a ed.), Universdide Federal de Viçosa, Viçosa, Minas Gerais, Brasil. 305p.

Silva, F. C. (2009). Manual de análises químicas de solos, plantas e fertilizantes. Embrapa Informação Tecnológica, 370p.

Silveira, R. K. (2020). Manejo ecofisiológico das gramíneas Megathyrsus maximus (Panicum maximum) cv. Tanzânia, Mombaça e Massai. Veterinária e Zootecnia, 27 (1), 1-13. https://doi.org/10.35172/rvz.2020.v27.421

Souza, J. A. S. (2018). Produção de gramíneas forrageiras dos gêneros Urochloa e Megathyrsus nas condições edafoclimáticas de Manaus, AM. $58 \mathrm{f}$. Dissertação. (Mestrado em Agronomia Tropical). Universidade Federal do Amazonas.

Tesk, C. R. M., Cavalli, J., Pina, D. S., Pereira, D. H., Pedreira, C. G. S., Jank, L., Sollenberger, L. E. \& Pedreira, B. C. (2020). Herbage responses of Tamani and Quênia guineagrasses to grazing intensity. Agronomy Journal, 201, 1-27. https://doi.org/10.1002/agj2.20189 